\title{
TUDÓSTANÁROK A KÖZOKTATÁSBAN
}

\section{Chrappán Magdolna}

\author{
a Debreceni Egyetem Bölcsészettudományi Karának \\ föiskolai docense \\ chrappanm@gmail.com
}

Tízegynéhány évvel ezelőtt végigsöpört az országon a nyolcosztályos gimnáziumok „mindenekfelett valóságának” szele. Nagyon sokan sorolták mellette a racionális és érzelmi érveket, sugallva, hogy ez a szerkezet jelentheti a közoktatás bajaira a gyógyírt. Túlnyomórészt olyan, egyébként saját területükön kiváló szakemberek, tudósok, akik maguk is ilyen intézményben végeztek. Érvelésüknek számtalan megfontolásra méltó eleme volt, sok energia és figyelem fordítódott a téma kutatására. Sok iskola a nyolc- és hatosztályos gimnáziumi képzések indításában látott menekülési utat abból a demográfiai apályból (valamint a közeli nagyvárosok elszívó hatását is ellensúlyozandó), amely a kilencvenes évek elejétől határozottan érzékelhető volt, különösen a közepes méretü településeken. Csak azok az iskolák lettek azonban sikeresek, amelyek olyan társadalmi közegben léteztek, olyan fenntartói-müködtetési paraméterekkel bírtak, amelyet oktatásszociológusok jóval korábban peremfeltételként határoztak meg ezeknél az iskolatípusoknál. Végül kiderült, hogy önmagában egy strukturális elem nem old meg, ahogyan nem is generál, alapvető közoktatási problémákat. Ezzel a példával analóg helyzetnek érzem az újra felerősödni látszó vitát, amely a tudóstanárok vs. pedagógia kérdését feszegeti a tanárképzésben.

Most, amikor lehetőség nyílik arra, hogy a tanárképzés Bologna-verzióját felülvizsgáljuk, a szócsaták kereszttüzébe kerül ismét a feloldhatatlan dilemma: diszciplína vagy pedagógia? Van-e tanár általában, vagy csak matematika-, fizika-, magyartanár létezik? Ugyanaz a paradigma-ütközés, csak más verbális köntösben. Persze tudjuk, nem törekszik kizárólagosságra sem a pedagógia, sem a szaktudomány, az állandó vitakérdés a tanárképzésen belüli arányuk.

Ám ennél is lényegesebb kérdés, hogy vajon ki az, aki erröl az arányról dönt? A tanárképzést az iskola (no meg persze, a tanárképzést folytató intézményi egységek) felől szemlélők azt gondolják, nekik kellene ezt a döntést meghozni, mert nekik van a legátfogóbb ismeretük az iskolarendszer müködéséről, következésképp a müködtetéshez szükséges tanárok felkészítéséről is. A tanárképzést a tudományos közösségek felől szemlélők azonban úgy érvelnek (alapvetően a felsőoktatásba bekerülő hallgatók általános és szakspecifikus input-tudása alapján), hogy tarthatatlan a közoktatás állapota, a tanárképzésben igenis újra a diszciplináris képzésnek kell a 
főszerepet kapnia, mert az egyre gyengébb tanárok keze közül egyre gyengébb tudású gyerekek kerülnek ki, akik bekerülve a felsőoktatásba egyre gyengébb tanárok lesznek, akik kezei közül... Pozitív feed-back, mindannyiunk tapasztalatai alátámasztják ezt az érvet is.

Többnyire ezen a ponton bukkan fel a tudóstanár, mint olyan tanáreszmény, aki megoldhatja a közoktatás számos problémáját, de az oktatási színvonal zuhanását mindenképpen ${ }^{1}$.

Tulajdonképpen kik is a tudóstanárok? Erre nemigen hallunk definíciókat, induljunk tehát innen. Többféle alternatíva kínálkozik, az egyik szerint tudóstanár az a - jobbára gimnáziumi - tanár, aki maga is intenzíven és eredményesen müveli szaktudományát. Ezt a megközelítést halljuk leggyakrabban, visszautalva régi idők nagy tanár alakjaira, akik alapvetően (bár nem kizárólag) a két világháború között kezdték pályájukat, és neveltek tudósgenerációkat, miközben maguk is termékenyen járultak hozzá koruk szaktudományos eredményeihez.

Egy másik lehetséges értelmezés szerint tudóstanár az, aki tanári tevékenységének minden mozzanatával a tudós- és kutató-utánpótlás oktatását szolgálja. Akiknek az igazi közege, szakmai specialitása a rendkívül erős diszciplináris felkészítés, e téren kiváló eredményeket érnek el az arra alkalmas diákokkal, és kétségtelenül óriási szerepük van abban, hogy a magyar tudományos potenciál erősödjék. Ez lágyabb definíció, hiszen a tanár tudományos eredményessége itt nem feltétlen elem, azonban a tudóstársadalom valószínüleg nem a tudományt professzionálisan müvelö tanárembert hiányolja, hanem azt a tanárt, aki képes kiváló tudóspalántákat nevelni! Ez jogos elvárás, a félreértést az okozza, hogy a tudóstanár kétféle megközelítése összecsúszik az érvelés során. Mint ahogy az is igaz, hogy ilyen feladatok megoldása során a nem kiváló szaktudományos képzettségú tanárok komoly károkat tudnak okozni, hiszen olykor nem ismerik fel, sőt, gyakran kifejezetten büntetik a gyerek kreatív, egyedi tudományos megoldásait, támogatás helyett gyakran elnyomják a kibontakozni készülő tehetséget. A szaktudományos bizonytalanság ráadásul súlyos szakmai hibákhoz, rugalmatlan gondolkodáshoz és sokszor agreszszivitáshoz vezethet, különösen, ha pszichológiai-pedagógiai-kommunikációs felkészületlenséggel is párosul.

Időzzünk el mégis néhány mondat erejéig a tudományt müvelö tudóstanár archetípusánál. Legtöbbször matematika-, fizika-, kémiatanárokról, irodalmárokról, nyelvészekről, etnográfusokról van szó, akik vagy a tanári munka mellett végeztek tudományos-müvészeti tevékenységet, vagy a tanári munka életük egyik fontos szakasza volt csupán. Utóbbiak közé tartoznak olyan kiváló müvészeink, mint Gárdonyi Géza, Móra Ferenc, Németh László, Váci Mihály, Szabó Magda, Jókai Anna,

\footnotetext{
${ }^{1}$ A tudóstanár igénye mögött egyértelmüen az a szándék húzódik meg, hogy a leendő tanárok a jelenleginél sokkal több szakdiszciplináris ismeretet tanuljanak, és ez a törekvés önmagában méltányolható is volna. A problémát az okozza, hogy a képzési félévek számának növelése nélkül ezt csak egyféleképpen lehet megoldani: a pedagógiai-pszichológiai modul jelentős visszaszorításával.
} 
hogy csak néhányat említsünk azok közül, akiknek a munkássága meghatározóan táplálkozik a tanári munkából. Mủveikből kiragyog a tudóstanár egyik jellegzetessége, amely a természettudós-tanárok pályaképéböl, de különösen a diákok visszaemlékezéseiből is egyértelmüen kiolvasható: a tudóstanárok tanárnak (úgy általában) is kiválóak voltak, amit a módszeres pedagógiai felkészültség, emberismeret és emberi tartás garantált. Képtelen és veszélyes is tehát szembeállítani a diszciplináris és a pedagógiai kvalitásokat, még annyira sem, hogy döntő prioritást rendelünk valamelyikhez. E ponton pedig ki kell jelentenünk azt is, nem elég, ha valaki született tanár: képezni is kell, a tanári kompetenciák mindegyike fejleszthető, elsajátítható. Vitathatatlan természetesen, hogy van, akinek jobbak a személyiségéből fakadó pedagógiai képességei, az empátia, nyitottság, humorérzék, kommunikációs, szociális kompetenciák stb., de ez nem kérdőjelezi meg az eredeti állítást.

A tudóstanárokra való hivatkozásokat érdemes abból a szempontból is vizsgálni, hogy kik és milyen kontextusban emlékeznek rájuk. Általában olyan tudósok szájából halljuk a tudóstanár-eszményt, akik erősen kötődnek az adott diszciplínához, és az illető tanártól kapták a kezdő stimulust a tudománnyal való elköteleződéshez, ráadásul maguk is kiváló elmék, az intellektuális elit élvonalához tartoznak. Ritkán halljuk azt, hogy valaki „,csak” átlagemberként ${ }^{2}$ jó szívvel és elismerően nyilatkozik saját tudóstanáráról, aki a tudománnyal megkeserítette iskolai mindennapjait, állandó kudarcot, esetleg kishitűséget alakítva ki ${ }^{3}$. Kivéve, ha az a tudóstanár kiváló tanár is volt egyben, aki nem pusztán a tudománnyal hat. Ezzel pedig ismét az alapoknál vagyunk: nincs tudóstanár jó tanárság nélkül. Emlegetett tudóstanáraink szinte kivétel nélkül gimnáziumi tanárok, akik valóban könnyebben tudják tudományos teljesítményükkel megragadni a felnőttkor küszöbén álló fiatalok figyelmét és elismerését. Az a feltevés pedig, hogy a gimnázium a felsőoktatásra készít fel, erősíti azt az elvárást, hogy ebben az intézménytípusban tudóstanárok legyenek. A baj csak az, hogy manapság a felsőoktatás sokkal szerteágazóbb, tömegesebb, mint akár egy-két évtizeddel ezelőtt, nem is beszélve a tudóstanár hőskoráról, a 19. század utolsó harmadáról és a 20. század első feléről. Megállapíthatjuk persze, hogy sajnos, a felsőoktatás sem jelent már kétségtelenül és minden szintjén tudományos képzést, hogy bizonyos intézménytípusban, vagy szakokon az alapképzés a jobb középiskolák átlagos színvonalát sem éri el egy-egy tudományterületen, de akkor azt is meg kell állapítanunk a tudományos elemzés következetességével, hogy ez nem közoktatási, és föleg nem tanárképzési probléma. Követke-

\footnotetext{
${ }^{2}$ Tekintsünk el most attól a ténytől, hogy átlagembereket nem is hallunk tudóstanárokról nyilatkozni, hiszen egyrészt nem tudják megítélni a tanár tényleges tudományos teljesítményét, másrészt nemigen szoktuk megkérdezni őket ilyen ügyekben.

${ }^{3}$ Önmagában a tudományok oktatása nem jár feltétlenül ilyen eredménnyel, de a mindennapi tapasztalat sajnos ezt mutatja. Komoly probléma, hogy zárt tudományos közegben ez egyszerüen nem érzékelhetö.
} 
zésképpen a tudóstanárok ezt a gondot a legcsekélyebb mértékben sem tudhatják orvosolni.

Sajnálatos félreértés a felsőoktatás tömegesedését és ennek negatív következményeit a tanárképzés tudósképzés irányába való eltolásával megoldhatónak vélni. Teljesen érthető, hogy lehetetlen az elitképzéshez szokott egyetemi oktató számára annak tudomásul vétele, hogy a BA-BSc-képzésekben együtt ülnek a legjobb 5-10\%-ba tartozó hallgatók azokkal, akik 15-20 évvel ezelött sokadik próbálkozásra sem jutottak volna be egyetlen egyetemre sem. A felsőoktatás tömegesedése - interferálva a „magyar bologna-folyamat” jól ismert keletkezési sajátosságaival - a tudományos képzés jogos input-igényeinek nyilvánvalóan nem tud megfelelni. Ezen azonban nemigen segíthet a tudóstanár, sőt, ne feledkezzünk meg arról a tényröl sem, hogy jelenleg csak olyan tanárok vannak a pályán, akik alapvetöen egyetemi tudósképzésben vettek részt $t^{4}$. Ha erőteljesebb tudományos képzést szeretnénk biztosítani a leendő tanároknak, akkor az is végiggondolandó, hogy elegendő-e a 10+1 félév.

De térjünk vissza a tudóstanárokhoz! Tételezzük fel érthetö igényként azt, hogy legalább a gimnáziumokban a tudományosság legyen a döntő minősítési elem. Nézzünk néhány idevonatkozó adatot a KSH adatbázisából:

1. táblázat: A 7 éves és idősebb népesség legmagasabb befejezett iskolai végzettség szerint $(\%)^{*}$

\begin{tabular}{|l|c|c|c|c|c|c|}
\hline & 1920 & 1970 & 1980 & 1990 & 2001 & 2005 \\
\hline $\begin{array}{l}\text { Középiskolai végzettség } \\
\text { érettségivel } \\
\text { (gimnázium }^{* *}+\text { szakközépiskola) }\end{array}$ & 1,9 & 9,4 & 14,6 & 16,2 & 22,7 & 25,2 \\
\hline Egyetemi, föiskolai oklevél & 1,0 & 3,2 & 5,1 & 7,6 & 9,8 & 11,7 \\
\hline
\end{tabular}

${ }^{*}$ http://www.nepszamlalas.hu/mc2005/mc2005_hun/kotetek/09/02_ert.pdf, letöltés: 2010. május 5.

** A gimnáziumi érettségi aránya 1980-2005 között 40-46 \% között ingadozik az összes érettségin belül, azaz a teljes népességnek maximum 10-12\%-át érinti.

A tudóstanár tehát olyan kor ideálja, amikor a teljes népesség alig néhány százaléka járt gimnáziumi képzésbe, és 1980-ig sem érte el a 10 \%-ot, arról nem is beszélve, hogy a tudomány múvelése is egészen más feltételek között folyhatott. Tegyük fel egy pillanatra, hogy a gimnáziumban manapság is a tudóstanár a valóban haté-

\footnotetext{
${ }^{4}$ E sorok szerzője 25 éve olyan kétszakos természettudományos tanárképzésben részesült, ahol az I-IV. évfolyamon a pedagógiai-pszichológiai tárgyak óraszámaránya $5 \%$ körül mozgott, és V. évfolyamon sem haladta meg az 50 \%-ot az iskolai gyakorlaton kívüli pedagógiai-módszertani óraszám. Az arányok drámaian nem módosultak az elmúlt évtizedben sem, kivéve természetesen a bolognai tanárképzést.
} 
kony modell! Ebben az esetben is az a helyzet, hogy a teljes populációra gyakorlatilag a 10\%-nak megfelelő tanárképzést akarnánk kizárólagossá tenni. Ezen szándékunk szerint azonban azt is állítanunk kell, hogy mindenki képes és mindenkinek szükséges is gimnáziumi érettségit szereznie, nemcsak 10\%-nak. Ellenkező esetben az a kép alakul ki, hogy társadalmilag érzéketlenek, az iskola szerepét anakronisztikusan szimplifikálók, csupán egy szük réteg hosszú távú érdekeit mindenek felettinek tekintők vagyunk. Ezt a rossz üzenetet pedig természetesen kerülni szeretnénk, ami csak úgy lehetséges, ha árnyaltabban és sokoldalúbban közelítünk az egész probléma-komplexumhoz.

A tudóstanárokra nagy szükség van, hiszen fontos, hogy a tudományos élvonal utánpótlását már a közoktatás befejező szakaszában is szaktudományosan kiválóan felkészült tanárok biztosítsák. Ebben az esetben is felmerülhet azonban néhány kérdés. Az egyik, hogy a tudóstanár milyen tudományt tanít: az egyetemi tananyagot (BSc? MSc?), vagy valami mást, például valamilyen nemzetközi standardhez (ha volnának ilyenek) igazodó tartalmakat? Az érintett diákok hol tanulnak: csak gimnáziumokban, bizonyos szakközépiskolákban, teljes osztályokban vegyesen, csak a tagozatokon, csak emelt óraszámú képzésben? Mi a teendő azokkal a gyerekkel, akik ugyancsak tudóstanárt igényelnek, csak egy másik tudományból: vagyis mindenki ugyanazt tanulja például kémiából akár vegyész, akár matematikus, akár nyelvész akar lenni? Mert ha iskolatípushoz kötjük a tudóstanárt, akkor ez bekövetkezhet. Sorjázhatnának még a hasonló tantervi, strukturális, differenciálással, összességében az iskolai funkciórendszerrel kapcsolatos kérdések, amelyek csak látszólag együgyủek, valójában egy komplex rendszer elemeire vonatkozó alapvető felvetések, és a jelenlegi terjedelemnél sokkal részletesebb kifejtést igényelnének.

Továbbá: tudóstanár tanít általános iskolában, szakiskolában, szakközépiskolában is? Milyen életkorhoz kössük a tudományos felkészítést? Tudjuk, hogy nagyon sok kisdiák van, aki csodálatos kognitív teljesítményre képes, jól bírják, sőt élvezik is a korai intellektuális terhelést, jó érzékü tudóstanárok nagy eredményekre segíthetik őket. Intézménytípushoz, vagy speciális képzési programokhoz rendeljük tehát a tudományos képzést? A tudóstanár óhajtása ugyanis ténylegesen azt a vágyat fejezi ki, hogy minél több, minél tudománycentrikusabb ismeretet tanítsanak az iskolában, és lehetőleg mindenki fogadja el, hogy ez az ideális megoldás. A tudóstanár tehát valójában egyfajta tantervi követelményrendszer tanári megtestesitöje.

De mi legyen a többiekkel (akár kicsik, akár nagyobbak), akik nem képesek a követelmények teljesítésére: tekintsük őket oktatási selejtnek? És ha kimondvakimondatlanul ezt tesszük, akkor milyen problémát oldottunk meg? Csupán egyet: kiválogattuk a tudományos felsőoktatás számára a potenciális jelölteket.

A kör itt be is zárul: egyetlen partikuláris, bár kétségtelenül fontos stratégiai célnak rendeljük alá nemcsak a teljes tanárképzést, hanem gyakorlatilag a közoktatás egészét is. Súlyos állítások ezek, de ha a teljes tanköteles népességet tekintjük, igazak. 
Az elmúlt időszakban sok oktatáspolitikai ötlet generálódott alapvetően helyeselhető társadalmi megfontolásból, de doktriner, hektikus és kontraproduktív módon megvalósítva. Ebből azonban nem következik sem az, hogy minden, az utóbbi évtizedben bevezetett dolognak az ellenkezője volna jó, sem pedig az, hogy a szaktudomány-uralta tanárképzés megnyugtató eredményeket hozna. Nehezen értelmezhető például az a nézet, hogy a képzés 300 kreditjéből szerzendő $10+40$ pedagógiai-pszichológiai kredit (1/6 rész) a diszciplínák súlyos érdeksérelmét jelentené.

Egy tanár értékelhető önmagában tanárként is, mert iskolai közegben a magyar- meg a fizikatanár mindennapi munkájában sokkal több a tanárságból fakadó közös, mint a tárgyak különbözőségéből eredő eltérő elem. Ez azonban nem legitimálja a gyenge diszciplináris - erős gyakorlati képzés modellt!

Véleményütközésekre, álláspontjaink érvekkel, statisztikákkal való megerősítésére szükség van, be kell mutatni, hogy jó tanár nincs alapos pedagógiai felkészítés nélkül, mint ahogy erôs és biztos szaktudományos tudás nélkül sem.

Egy azonban bizonyos: a megfelelő arányok nem állapíthatók meg, és föképp nem dönthetők el egy-egy aktuálisan erös szakmai lobbi iskolaképe alapján.

\footnotetext{
${ }^{5}$ A szakmódszertani és a szaktárgyi tanítási gyakorlat kreditjeit a szaktudományok inkább tekintik a sajátjuknak.
} 